\title{
Macroscopic Examination of Semen Quality from Infertile Patients Fed with Supplement from Anadara granosa L
}

\author{
Eddyman W. Ferial ${ }^{1,3}$, Ahyar Ahmad ${ }^{1,2, *}$ \\ ${ }^{1}$ Laboratory of Research Centre and Developing of Sciences, Faculty of Natural Sciences, Hasanuddin University, Makassar, Indonesia \\ ${ }^{2}$ Department of Chemistry, Faculty of Natural Sciences, Hasanuddin University, Makassar, Indonesia \\ ${ }^{3}$ Department of Biology, Faculty of Natural Sciences, Hasanuddin University, Makassar, Indonesia
}

\section{Email address:}

eddymanwferial@yahoo.com (E.W. Ferial),ahyarahmad@gmail.com (A.Ahmad)

\section{To cite this article:}

Eddyman W. Ferial, Ahyar Ahmad. Macroscopic Examination of Semen Quality from Infertile Patients Fed with Supplement from Anadara granosa L. International Journal of Nutrition and Food Sciences. Vol. 4, No. 4, 2015, pp. 453-458. doi: 10.11648/j.ijnfs.20150404.16

\begin{abstract}
A study on macroscopic examnination of semen quality from infertile patients after being fed with supplement from marine clam, Anadara granosa L.was conducted. The objective of this study was to analyze the difference of sperm quality from the treated patients before and after they consumed nutrients from A. granosa L. Semen samples were taken from infertile patients and analyzed at the Prodia Laboratory, Makassar, Indonesia. The clam samples were collected from Pannaikiang Island, District of Barru, South Sulawesi, Indonesia. Data analysis applied T-test in order to know the difference of sperm quality before and after administration of supplement from A. granosa L. Placebo administration of 1 capsule per day did not affect the macroscopic characteristics (volume, $\mathrm{pH}$, odor, and color) of collected sperm. Administration of one capsule per day and two capsules per day significantly improved the macroscopic characteristics of the sperm.
\end{abstract}

Keywords: Macroscopic, Semen, Anadara granosa L, Infertility

\section{Introduction}

Infertility is one of the disturbances in reproduction health. Infertility is defined as disability to yield conception after regular intercourse without using any contraceptive within a year (Rowe et al., 2000). Approximately 30\% of infertility causes is man factor that is the abnormal quality of spermatozoa (Jonson, 2003). Spermatozoa quality is determined by the amount, motility, and morphology of spermatozoa (World Health Organization, 1999).

Tandean (2009) stated that there are several causes responsible for infertility, namely, 1) decrease of sperm motility as a result of mitochondria dysfunction causing less supply of energy, and 2) dysfunction of non-genomic progesterone receptor.

The general causes for infertility in men are abnormal morphology and mobility, low concentration of spermatozoa, no semen, varicocele, testes do not move down, lack of testosterone, genetic disorder, infection, sexual problem, reverse ejaculation, blockage in epidiymis, hypoepispadia, sperm-killing antibody, cystic fibrosis, testicular cancer.

Aside from the causes for infertility, one of the causes for the decrease of spermatozoa quality in men might be due to the lack of zinc $(\mathrm{Zn})$, which is important for reproduction. According to Lewis (1996), $\mathrm{Zn}$ plays crucial role in production and viability, prevents degradation and maintains membrane stability of spermatozoa. Zn deficiency leads to impotency and hypogonadism (Bedwal, 1994). Another research showed that zinc concentration in infertile men was lower than that in fertile men (Chia, 2000). While, calcium (Ca) is needed for physiological process of spermatozoa including mobility, metabolism, acrosome reaction and fertilization (Lendenmann, 1987; Yanamigachi, 1981).

Because of its nutrient content, clams can be used as food supplement to improve the quality of spermatozoa in men. Fats or cholesterol from clams can serve as precursor for the synthesis of testosterone, a hormone that functions for spermatozoa maturation (Soeharso, 2004). Men who consume moderate fats containing mono-unsaturated fatty acid and saturated fatty acids possess higher concentration of testosterone than those who consume less fat (Soeharso, 2004).

Based on data reported previously, infertility in men has caused $40 \%$ of couple infertility and the availability of information on nutrient content in $A$. granosa $L$. The research was conducted to know the different effect of administration of supplement from $A$. granosa $L$. on the macroscopic 
characteristics of semen from infertile men.

\section{Materials and Methods}

\subsection{Materials and Experimental Design}

This research was a pre-experimental study by one group pre-test and post-test on macroscopic quality of semen, by which a measure was taken before a treatment (pre-test) followed by another measure after treatment (post-test). Clams $A$. granosa L. was taken from Panikiang Island, Sub-District of Tanete Rilau, District of Barru, South Sulawesi, Indonesia. Supplement capsules of A. granosa L were prepared by standard of maseration by Culei (1984) in the Laboratory of Product Development, The Center for Food, Nutrition, and Health Research, Hasanuddin University. Samples of semen were obtained from infertile patients in WahiddinSudirohusodo hospital and analyzed in Prodia Laboratory, Makassar, Indonesia. The pictures of samples were taken in the National Reference Center.

\subsection{Respondents}

This experiment involved 36 respondents who were chosen from the 150 patients participated in the previous research showing an indication of infertility symptoms. The respondents were 22-40 years old. The respondents were divided into 3 groups consisting of 12 patients. The first group was given 1 capsule $A$. granosa L. supplement per day; the second group took 2 capsules per day; and the third group was as control given 1 capsule placebo per day.

\subsection{Sample Collection}

Sperms were collected in the laboratory from infertile men who were fasting sexual intercourse for 3-4 days

\subsection{Data Analysis}

Data were collected through anamnesis and physical examination. Macroscopic analysis of semen characteristics, including volume, $\mathrm{pH}$, color, and viscosity, was done clinically according to WHO standards. Quantitative data of the sperm quality were analyzed before and after the administration of supplement from clam A. granosa $\mathrm{L}$ and placebo according to previously methods (Ferial, 2011). The data were statistically analyzed using SPSS 16.0 software Program.

\section{Results}

The preliminary study of nutritional quality parameters of $A$. granosa $L$.were determined by standard analitical methods, with particular observed in the nutrient content, with particular regard the protein to average value of $62.20 \%$, carbohydrate of $3.1 \%$, lipid of $22.40 \%$, Calsium of $3.87 \mathrm{ppm}$, Iron of $155.8 \mathrm{ppm}$, Copper of $13.5 \mathrm{ppm}$, and Zinc of 40.26 ppm in $A$. granosa L. powder.

The result of Pre-Test and Post-Test on the sperm quality of the control group after treatment with placebo $1 \mathrm{x} 1$ is shown in the Table 1 to 5 .

Table 1. Pre-Test and Post-Test Results on the Quality of Sperm of the Control Group after Placebo $1 \times 1$.

\begin{tabular}{llllll}
\hline \multirow{2}{*}{ Dose } & \multirow{2}{*}{ No. } & \multicolumn{2}{l}{ Volume $(\mathbf{m L})$} & $\mathbf{p H}$ & \\
\cline { 3 - 6 } & & Pre-Test & Post-Test & Pre-Test & Post-Test \\
\hline \multirow{4}{*}{ Placebo } & 1 & 1.8 & 1.8 & 8.3 & 8.2 \\
& 2 & 1.5 & 1.6 & 8.1 & 8.0 \\
& 3 & 1.6 & 1.6 & 8.1 & 8.1 \\
& 6 & 1.7 & 1.7 & 8.3 & 8.1 \\
& 4 & 1.8 & 1.8 & 8.5 & 8.5 \\
& 5 & 1.8 & 1.9 & 7.9 & 7.9 \\
& 8 & 1.5 & 1.8 & 8.3 & 8.3 \\
& 9 & 1.6 & 1.6 & 8.1 & 8.1 \\
& 10 & 1.7 & 1.6 & 8.1 & 8.1 \\
& 11 & 1.8 & 1.7 & 8.3 & 8.3 \\
& 12 & 1.9 & 1.9 & 8.5 & 8.4 \\
\hline
\end{tabular}

Change on semen volume before and after treatment of control group

Table 2. T-Test on the semen volume of control group.

\begin{tabular}{llll}
\hline Volume of Semen & & Mean & p Value \\
\hline \multirow{2}{*}{ Volume } & Pre-test & 1.7167 & 0.166 \\
& Post-test & 1.7333 & \\
\hline
\end{tabular}

T-test result (above) showed that there was no significant improvement on volume of semen after placebo 1 capsule per day $(\mathrm{p}=0.166)$.

$\mathrm{pH}$ of the semen before and after the treatment of the control group

Table 3. T-test on the pH of semen of the control group.

\begin{tabular}{lll}
\hline ph of Semen & Mean & p Value \\
\hline Pre-Test & 8.2000 & 0.069 \\
Post-Test & 8.1625 & \\
\hline
\end{tabular}

Table 4. The Odor of the semen samples before and after the treatment of the control group.

\begin{tabular}{|c|c|c|c|}
\hline \multirow{2}{*}{ Sample No } & \multicolumn{2}{|l|}{ Odor } & \multirow{2}{*}{$\begin{array}{l}\text { p Value from } \\
\text { Wilcoxon post Test }\end{array}$} \\
\hline & Pre-Test & Post-Test & \\
\hline 1 & Typical & Typical & \multirow{12}{*}{1.000} \\
\hline 2 & Typical & Typical & \\
\hline 3 & Typical & Typical & \\
\hline 4 & Typical & Typical & \\
\hline 5 & Typical & Typical & \\
\hline 6 & Typical & Typical & \\
\hline 7 & Typical & Typical & \\
\hline 8 & Typical & Typical & \\
\hline 9 & Typical & Typical & \\
\hline 10 & Typical & Typical & \\
\hline 11 & Typical & Typical & \\
\hline 12 & Typical & Typical & \\
\hline
\end{tabular}

T-test result (above) showed that there was no significant improvement on $\mathrm{pH}$ of semen after placebo 1 capsule per day $(\mathrm{P}=0.169)$. 
Odor of the semen before and after the treatment of the control group

Basically, the odor of the semen samples was not abnormal. This can be seen from the laboratory test results as shown in the Table 4.

After statistical analysis using Wilxocon test, the obtained $\mathrm{p}$ value was 1.000 , indicating no difference in odor before and after placebo 1 capsule per day. All sperm samples showed specific odor.

Color of the semen before and after the treatment of the control group

Basically, the color of semen samples did not undergo abnormality on infertility patients. This can be seen from the laboratory test results (Table 5).

Table 5. Color of the semen before and after the treatment of the control group.

\begin{tabular}{llll}
\hline \multirow{2}{*}{ Sampel No. } & Color & \multicolumn{1}{c}{$\begin{array}{l}\text { p Value from } \\
\text { Wilcoxon post Test }\end{array}$} \\
\cline { 2 - 3 } & Pre-Test & Post-Test & \\
\hline 1 & White grayish & White grayish & \\
2 & White grayish & White grayish & \\
3 & White grayish & White grayish & \\
4 & White grayish & White grayish & \\
6 & White grayish & White grayish & \\
7 & White grayish & White grayish & \multirow{2}{*}{1.000} \\
8 & White grayish & White grayish & \\
9 & White grayish & White grayish & \\
10 & White grayish & White grayish & \\
11 & White grayish & White grayish & \\
12 & White grayish & White grayish & \\
\hline
\end{tabular}

After statistical analysis using Wilxocon test, the $\mathrm{p}$ value was 1.000 , indicating no difference in color before and after placebo 1 capsule/day. All sperm samples showed normal color.

Pre-Test and Post-Test Results on the Quality of Sperm of the Case Group after Administration of Supplement from $A$. granosa L. 1 capsule per day

The quality parameters of semen from infertile patients before and after treatment are shown in the Table 6.

Table 6. Pre-Test and Post-Test Results on the Quality of Semen of the Infertile Group Treated with Supplement of A. granosa L.

\begin{tabular}{llllll}
\hline \multirow{2}{*}{ Dose } & \multirow{2}{l}{ No. } & \multicolumn{3}{l}{ Volume $(\mathbf{m L})$} & \\
\cline { 2 - 6 } & & Pre-Test & Post-Test & Pre-Test & Post-Test \\
\hline & 1 & 1.7 & 2.00 & 8.1 & 7.80 \\
& 2 & 1.7 & 2.10 & 8.3 & 7.70 \\
& 3 & 1.5 & 2.20 & 8.1 & 8.30 \\
& 4 & 1.7 & 2.00 & 8.3 & 7.50 \\
Supplement & 5 & 0.9 & 2.00 & 8.1 & 7.60 \\
of Anadara & 6 & 1.3 & 2.00 & 8.1 & 7.50 \\
granosa L. 1 & 7 & 1.6 & 1.60 & 8.1 & 7.80 \\
X 1 & 8 & 1.5 & 1.50 & 8.3 & 7.70 \\
& 9 & 1.6 & 1.60 & 8.1 & 8.10 \\
& 10 & 1.7 & 2.00 & 8.3 & 7.50 \\
& 11 & 1.1 & 2.00 & 8.1 & 7.70 \\
& 12 & 1.3 & 2.00 & 8.1 & 7.60 \\
\hline
\end{tabular}

Change on semen volume before and after treatment on the case group

Table 7. Average Volume of Semen from Infertile Groups before and after treatment with Supplement of A. granosa L. 1 capsule per day.

\begin{tabular}{lll}
\hline Semen Volume & Mean & p Value \\
\hline Pre-test & 1.466 & 0.000 \\
Post-test & 1.916 & \\
\hline
\end{tabular}

The above t-test result (Table 7) shows that there was a significant improvement on semen volume of the patients after treatment with A.granosa L. supplement 1 capsule per day ( $p$ $=0.000)$.

Change on semen $\mathrm{pH}$ before and after treatment for the case group

Table 8. Average $p H$ of Semen from Infertile Groups before and after treatment with Supplement of A. granosa L. 1 capsule per day.

\begin{tabular}{lll}
\hline Semen pH & Mean & p Value \\
\hline Pre-test & 8.166 & 0.000 \\
Post-test & 7.733 & \\
\hline
\end{tabular}

The above t-test result (Table 8) shows that there was a significant improvement on semen $\mathrm{pH}$ of the patients after treatment with Anadaragranosa L. supplement 1 capsule per day $(\mathrm{p}=0.000)$.

Change on semen odor before and after treatment for the case group

Basically, the odor of semen samples did not undergo abnormality on infertile patients. This can be seen from the laboratory test results as shown in Table 9.

Table 9. Change on semen odor before and after treatment on case group with supplement of A. granosa L. 1 capsule/day.

\begin{tabular}{|c|c|c|c|}
\hline \multirow{2}{*}{ Sampel No. } & \multicolumn{2}{|l|}{ Odor } & \multirow{2}{*}{$\begin{array}{l}\text { p Value from } \\
\text { Wilcoxon post Tes }\end{array}$} \\
\hline & Pre-Test & Post-Test & \\
\hline 1 & Typical & Typical & \multirow{12}{*}{1.000} \\
\hline 2 & Typical & Typical & \\
\hline 3 & Typical & Typical & \\
\hline 4 & Typical & Typical & \\
\hline 5 & Typical & Typical & \\
\hline 6 & Typical & Typical & \\
\hline 7 & Typical & Typical & \\
\hline 8 & Typical & Typical & \\
\hline 9 & Typical & Typical & \\
\hline 10 & Typical & Typical & \\
\hline 11 & Typical & Typical & \\
\hline 12 & Typical & Typical & \\
\hline
\end{tabular}

After statistical analysis using Wilxocon test, the obtained $\mathrm{p}$ value was 1.000 , indicating no difference in odor before and after placebo 1 capsule per day.

Change on semen color before and after treatment for the case group

Preliminary test on semen color showed abnormal change. This can be seen from the laboratory test result in the Table 10. 
Table 10. Change on semen color before and after treatment on case group with A. granosa L. supplement 1 capsule per day.

\begin{tabular}{llll}
\hline $\begin{array}{lll}\text { Sampel } \\
\text { No. }\end{array}$ & Color & $\begin{array}{l}\text { p Value from } \\
\text { Wilcoxon post Test }\end{array}$ \\
\cline { 2 - 3 } 1 & Pre-Test & Post-Test & White grayish \\
2 & White grayish & White grayish & \\
3 & White grayish & White grayish & \\
4 & White Yellowish & White grayish & \\
5 & White Yellowish & Whish & \\
6 & White grayish & White grayish & White grayish \\
7 & White grayish & White grayish & \\
8 & White grayish & White grayish \\
9 & White grayish & White & White grayish \\
10 & White Yellowish & White grayish \\
11 & White Yellowish & White grayish & White grayish \\
12 & White grayish \\
\hline
\end{tabular}

After statistical analysis using Wilxocon test, the obtained $\mathrm{p}$ value was 0.046 , indicating that there was an improvement of semen color after pretreatment with 1 capsule per day of $A$. granosa L. supplement.

Pre-Test and Post-Test Results on the Quality of Sperm of the Case Group after Administration of Supplement from $A$. granosa L. 2 capsules per day

Evaluation of semen quality of the infertile patients before and after administration of 2 capsules per day of $A$. granosa $\mathrm{L}$. supplement is shown in the Table 11.

Table 11. Pre-Test and Post-Test Results on the Quality of Semen of the Infertile Group Treated with 2 capsules per day of A. granosa L Supplement.

\begin{tabular}{|c|c|c|c|c|c|}
\hline \multirow{2}{*}{ Dose } & \multirow{2}{*}{ No } & \multicolumn{2}{|c|}{ Volume (mL) } & \multicolumn{2}{|c|}{ pH Value } \\
\hline & & Pre-Test & Post-Test & Pre-Test & Post-Tes \\
\hline \multirow{12}{*}{$\begin{array}{l}\text { Supplement } \\
\text { of } A \text {. } \\
\text { granosa } \mathrm{L} \text {. } \\
2 \times 1\end{array}$} & 1 & 1.2 & 2.3 & 8.5 & 7.8 \\
\hline & 2 & 1.5 & 2.3 & 8.1 & 7.7 \\
\hline & 3 & 1.7 & 2.2 & 8.5 & 7.8 \\
\hline & 4 & 1.2 & 2.2 & 8.1 & 7.5 \\
\hline & 5 & 1.3 & 2.3 & 8.1 & 7.3 \\
\hline & 6 & 1.7 & 2.2 & 8.5 & 7.2 \\
\hline & 7 & 1.2 & 2.0 & 8.5 & 7.8 \\
\hline & 8 & 1.5 & 2.3 & 8.1 & 7.7 \\
\hline & 9 & 1.8 & 2.4 & 8.5 & 7.8 \\
\hline & 10 & 1.2 & 2.2 & 8.1 & 7.5 \\
\hline & 11 & 1.3 & 2.1 & 8.1 & 7.3 \\
\hline & 12 & 1.6 & 2.2 & 8.5 & 7.2 \\
\hline
\end{tabular}

Change on semen volume before and after treatment for the case group

Table 12. Average Volume of Semen from Infertile Groups before and after treatment with 2 capsules per day of A. granosa L. Supplement.

\begin{tabular}{lll}
\hline Semen Volume & Mean & P Value \\
\hline Pre-test & 1.433 & 0.000 \\
Post-test & 2.225 & \\
\hline
\end{tabular}

The above t-test result shows that there was a significant improvement on semen $\mathrm{pH}$ of the patients after treatment with A.granosa L. supplement 2 capsules per day $(\mathrm{p}=0.000)$.

Change of Semen $\mathrm{pH}$ from Infertile Groups before and after treatment with $A$. granosa L. Supplement 2 capsules per day

Table 13. Average $p H$ of Semen from Infertile Groups before and after treatment with 2 capsules per day of A. granosa L. Supplement.

\begin{tabular}{lll}
\hline Semen $\mathbf{p H}$ & Mean & p Value \\
\hline Pre-test & 8.300 & 0.000 \\
Post-test & 7.550 & \\
\hline
\end{tabular}

The above t-test result shows that there was a significant improvement on semen $\mathrm{pH}$ of the patients after treatment with A.granosa L. supplement 2 capsules per day $(\mathrm{p}=0.000)$.

Change on semen odor before and after treatment for the case group

Basically, the odor of semen samples did not undergo abnormality on infertility patients. This can be seen from the laboratory test results as shown in Table 14.

Table 14. Change on semen odor before and after treatment on case group with 2 capsules per day of A. granosa L. supplement.

\begin{tabular}{|c|c|c|c|}
\hline \multirow{2}{*}{ Sampel No. } & \multicolumn{2}{|l|}{ Odor } & \multirow{2}{*}{$\begin{array}{l}\text { p Value from } \\
\text { Wilcoxon post Test }\end{array}$} \\
\hline & Pre-Test & Post-Test & \\
\hline 1 & Typical & Typical & \multirow{12}{*}{1.000} \\
\hline 2 & Typical & Typical & \\
\hline 3 & Typical & Typical & \\
\hline 4 & Typical & Typical & \\
\hline 5 & Typical & Typical & \\
\hline 6 & Typical & Typical & \\
\hline 7 & Typical & Typical & \\
\hline 8 & Typical & Typical & \\
\hline 9 & Typical & Typical & \\
\hline 10 & Typical & Typical & \\
\hline 11 & Typical & Typical & \\
\hline 12 & Typical & Typical & \\
\hline
\end{tabular}

After statistical analysis using Wilxocon test, the obtained $p$ value was 1.000 , indicating that there was no improvement of semen odor after pretreatment with 2 capsules per day of $A$. granosa L. supplement.

Change on semen color before and after treatment for the case group

Basically, the color of semen samples did not undergo abnormality on infertile patients. This can be seen from the laboratory test results as shown in Table 15.

Table 15. Change on semen color before and after treatment on case group with 2 capsules per day of A. granosa L. supplement.

\begin{tabular}{llll}
\hline \multirow{2}{*}{ Sampel No. } & Color & p value from \\
\cline { 2 - 3 } & Pre-Test & Post-Test & Wilcoxon post Test \\
\hline 1 & White grayish & White grayish & \\
2 & White grayish & White grayish & \\
3 & White grayish & White grayish & \\
4 & White grayish & White grayish & \\
5 & White grayish & White grayish & \\
6 & White grayish & White grayish & \multirow{2}{*}{1.000} \\
7 & White grayish & White grayish & \\
8 & White grayish & White grayish & \\
9 & White grayish & White grayish & \\
10 & White grayish & White grayish & \\
11 & White grayish & White grayish & \\
12 & White grayish & White grayish & \\
\hline
\end{tabular}


After statistical analysis using Wilxocon test, the obtained $\mathrm{p}$ value was 1.000 , indicating that there was no change of semen color after pretreatment with 2 capsules per day of $A$. granosa L. supplement.

\section{Discussion}

At macroscopic examination, the normal color of semen is grayish white or pearly white. In this experiment, the color of semen for all treatments was grayish white, a normal color. If the color of semen is translucent, it indicates that the semen is dilute, if red blood cells are present in the semen, then the color of semen turns brownish, due to hemoglobin (Wibisono, 2010). The normal color of semen looks like glue or gelatinized starch, which is grayish white. After long abstinence it changes to yellowish white (Yatim, 1982).

In terms of the odor of semen, all treatments showed specific smell of semen. Wibisono (2010) stated that semen has specific odor like that of acacia, if fishy or bad smell exists, it might be due to the presence of leukocyte (infection) or other causes (parasites).

Volume can be measured using graduated cylinder or special pipette. According to Yatim (1982), average volume of human semen is $2.5-3.5 \mathrm{~mL}$, but Freund (1987) reported that normal volume of semen ranges 1 - $5 \mathrm{~mL}$. For control group, administration of placebo 1 capsule per day did not affect the volume of semen. However, the treatment with $A$. granosa $\mathrm{L}$. supplement with 1 or 2 capsules per day could improve the volume of semen from the infertile patients.

Examination of semen viscosity was done using special needle or Eliasson pipette. Semen is said to be normal if it comes out from the needle-tip drop-by-drop and be abnormal if it forms a threat-like shape more than $2 \mathrm{~cm}$ long. For normal semen, the first drop drips within 2 seconds. Table 7 shows that treatment on control group did not improve semen viscosity. However, treatment with $A$. granosa L. supplement on case groups showed an improvement on semen viscosity. According to Hermanto (2000), semen which is too dilute or too viscous is not good for spermatozoa. In very viscoussemen, the movement of spermatozoa becomes slow. Hence, it can decrease fertility in men. Likewise, in very dilute semen, the number of sperm cells is very low leading to low fertility.

$\mathrm{pH}$ constitutes an important parameter of semen quality. $\mathrm{pH}$ must be measured within 1 hour after semen is collected. The normal $\mathrm{pH}$ value ranges from $7.2-8.0$ (WHO, 1992) or $7.2-7.8$ (WHO, 1987). If the $\mathrm{pH}$ value is higher than 8.0 , it should be suspicious for an infection. On the other hand, if the $\mathrm{pH}$ value is less than 7.0 with azoospermia, it is most likely to have disgenesia from vas deferens, vesicaseminalis, or epididymis. The examination showed that the $\mathrm{pH}$ of semen from control group did not change after treatment. But the $\mathrm{pH}$ of semen from the case groups showed an improvement after treatment with 1 or 2 capsules of $A$. granosa L. supplement per day, indicating good quality of semen.

\section{Conclusions}

Based on the macroscopic examination as mentioned above, it can be concluded that administration of placebo to control group did not result in improvement of semen quality but treatment with 1 or 2 capsules of $A$. granosa $L$. supplement per day could improve the quality of semen.

\section{Acknowledgements}

The author thanks Ahmad M. Mangnguluang for invaluable help and technical assistance, and the head of Biochemistry Laboratory and the Laboratory of Product Development, The Center for Food, Nutrition, and Health Research, of Hasanuddin University Indonesia for sample preparation and chemical analysis. The author also thanks Paulina Taba for editorial reading of the manuscript.

\section{References}

[1] Bedwal, R.S., and Bahaguna A. 1994. Zn, Copper and Selenium in Reproduction, Experientia, Vol. 50:626-640.

[2] Chia, S.E., Lim, S.T., Tay, S.K., and Lim, S.T.2000. Factors associated with male infertility: a case-control study of 218 infertile and 240 fertile men.BJOG. 107(1): 55-61.

[3] Culei, J. 1984. Metodology for Analysis of Vegetables and Drugs. Faculty of Pharmacy: Bucharest, Pp. 11-26.

[4] Ferial, E. W. 2011. The Clinical Study of Anadara granosa L Mollusk Shell Nutrient on Spermatozoid Quality of Human. (Disertation). Graduate Medical Sciences program, University of Hasanuddin, Makassar, Indonesia.

[5] Freund, M.,dan Peterson, M. 1976. Semen Evaluation and fertility.In :Human Semen and Fertility Regulation in Men. Edit by E.S.E Hafez. Saint Louis the C.V. Mosby Comp (1976) page $344-354$.

[6] Hermawanto H.H. 2000. Analysis ofSperminMale Infertility. Clinical PathologyPPDSHospital Dr.SyaifulAnwarMalang. Malang.

[7] Johnson, J.V. 2003. Infertility, in Scott JR, Gibbs RS, Karlan BY, Haney AF (editor), Danforth's Obstetrics and Gynecology, edition 9th, Lippincott Williams and Wilkins. USA.

[8] Lewis, Jones, D.I., Aird I.A., Biljan M.M., and Kingsland C.R. 1996. Effect of Sperm Activity on $\mathrm{Zn}$ and Fructose Concentration in Seminal Plasma. Human Reproduction, Vol. $11: 2465-2467$.

[9] Lindenmann, C.B., Goltz J.S., dan Kanous K.S. 1987. Regulaiton of Activation State and Flagellar Wafe Form in Epididymal Rat Sperm : Evidence for the involvement of both $\mathrm{Ca}+{ }^{2}$ and cAMP, Cellular Motility Cytoskeleton, Vol $8: 324-$ 332 .

[10] Ministry of Health. 2008. Kepmenkes No. 125 / Menkes / SK / II / 2008 on Guidelines for Community Health Insurance (JAMKESMAS) in 2008, Jakarta.

[11] Mukti. B. 2006. Design and Sample Size For Quantitative and Qualitative Research in the Field of Health, Gadjah Mada University Press, Yogyakarta. 
[12] Rowe P.J., Frank H.C., Timothy B.H., and Ahmed M.A.M. 2000. WHO Manual for the standardized Investigation, Diagnosis and Management of the Infertile Male, Cambridge University Press. UK.

[13] Setyono, D.E.D. 2006. Characteristics of Marine Biology and oyster products. Oseana Volume XXXI, Number I: Page. 5.

[14] Soeharso, P. 2004. Molecular Biology in Reproduction Hormon. Majalah Kedokteran Indonesia, Vol. 54, No. 3

[15] Sugiyono. 2008. Methods of Research Administration, Alfabeta, Bandung.

[16] Tendean, O. S., 2009. Fertilization Sperm. Faculty of Medicine, University of Sam Ratulangi, Manado.
[17] Wibisono, H. 2010. Atlas Spermatology. Refika Aditama Publisher, Bandung.

[18] Wibisono, H. 2010. Andrology Laboratorium Guide Book. Refika Aditama, Bandung.

[19] World Health Organization. 1999. WHO Laboratory Manual for the Examination of Human Semen and semen - Cervical Mucus Interaction, 4th ed. Cambridge University Press, U.

[20] Yanamigachi, R. 1981. Mechanism of Fertilization in Mammals, Mastroianni Jr., Biggers J.D., (editor), Fertilization and Embryonic Development In Vitro. Plenum Press, New York.

[21] Yatim, W. 1990. Reproduction and Embryology. Publisher Tarsito, Bandung. 